DOI 10.15290/cnisk.2021.02.11.06

MARIA BAUCHROWICZ-TOCKA

https://orcid.org/0000-0003-1691-2568

Uniwersytet w Białymstoku

\title{
Liga Kobiet wśród autochtonek na Górnym Śląsku w pierwszych latach $\mathrm{PRL}^{1}$
}

\section{Streszczenie}

W latach 1945-1950 autochtonki na Górnym Śląsku przechodziły weryfikację narodowościową i repolonizację. Procesy te zrodziły nieufność do polskiej administracji i Ligi Kobiet, która utożsamiana była $z$ nowa władzą. Autochtonki nie uczestniczyły w życiu publicznym i społecznym. Działaczki Ligi sporadycznie podejmowały próby włączenia Ślązaczek w pracę organizacji. Sytuacja zmieniła się w czasie wdrażania planu sześcioletniego.

Słowa kluczowe: Górny Śląsk, Liga Kobiet, autochtoni, repolonizacja

\footnotetext{
$1 \quad$ Artykuł przygotowany w ramach realizacji projektu badawczego Narodowego Centrum Nauki pt. „Liga Kobiet w terenie. Działalność organizacji i realia jej funkcjonowania na szczeblu regionalnym i lokalnym w rzeczywistości Polski Ludowej (1945-1989)", nr 2017/25/B/ HS3/02015.
} 


\section{WOMEN'S LEAGUE AMONG INDIGENOUS WOMEN IN UPPER SILESIA IN THE FIRST YEARS OF THE POLISH PEOPLE'S REPUBLIC}

In the years 1945-1950, the autochthons in Upper Silesia underwent nationality verification and repolonization. These processes gave rise to distrust of the Polish administration and the Women's League, which was identified with the new government. The indigenous people did not participate in public and social life. The League's activists made sporadic attempts to include Silesian women in the work of the organization. The situation changed with the implementation of the six-year plan.

Keywords: Upper Silesia, Women's League, indigenous people, repolonization

\section{Uwagi wstępne}

Na Górnym Śląsku w pierwszych latach po drugiej wojnie światowej była skomplikowana sytuacja demograficzna i polityczna. $\mathrm{Na}$ tereny $z$ dominująca społecznością śląska (miejscowa), nazywana autochtonami, przesiedlano repatriantów z Kresów Wschodnich, a wysiedlano Niemców i zgermanizowanych Ślązaków, uznawanych za ludność niemiecką. Na Śląsku osiedlali się także mieszkańcy centralnej Polski, którzy przyjeżdżali do pracy w kopalniach i w hutach. Społeczeństwo było zróżnicowane kulturowo i językowo. Rdzenni mieszkańcy, z odrębna historią, obyczajami, kultura i językiem, w tej społeczności tworzyli naród śląski (za taki siebie uznawali), chociaż oficjalnie nie było i nie ma takiej narodowości².

Ślazacy mieszkali na terenach wcześniej należacych do państwa niemieckiego. Niemcy prowadzili aktywna akcję germanizacji. W 1941 r. ogłosili Niemiecką Listę Narodową (tzw. volkslista), na która wpisani zostali Polacy lub zmuszeni byli do jej podpisania ${ }^{3}$. Po wojnie polskie władze traktowały Ślazaków w dwojaki sposób. $Z$ jednej strony byli oni historycznym dowodem $i$ atutem potwier-

\footnotetext{
2 „Naród śląski, narodowość śląska, nie istnieje w powszechnej świadomości, ani też w aktach prawnych. Postrzeganie odrębności Ślązaków (językowe, obyczajowe...) wiąże się raczej z historycznymi regionami (Górny Śląsk, Dolny Śląsk, Śląsk Cieszyński) kraju, a nie z istnieniem narodu śląskiego", stwierdził Sąd Najwyższy; Postanowienie SN - III SK 20/06 [online] [dostęp: 1.06.2020]. Dostępny w World Wide Web: https://prawo.money.pl/orzecznictwo/ sad-najwyzszy/postanowienie.

3 Wojciech Roszkowski, Historia Polski 1914-1991, (Warszawa: Wydawnictwo Naukowe PWN, 1992), 95.
} 
dzającym prawa Polski do terenów Śląska. $Z$ drugiej zaś strony traktowani byli $z$ nieufnościa i podejrzewani o sprzyjanie niemczyźnie. Władze pamiętały o podpisanych listach, wielu uznawały za spolonizowanych Niemców lub za zgermanizowanych Polaków. Autochtoni przechodzili weryfikację i repolonizację . Często rodowici Polacy udowadniali swoja narodowość przynależnością do Kościoła katolickiego i powoływaniem się na rodowód. Pozytywna weryfikacja chroniła przed wysiedleniem ${ }^{5}$.

Działaczki Ligi Kobiet ${ }^{6} \mathrm{w}$ Katowicach, które zabiegały o nowe członkinie i organizowały różnorodna pomoc kobietom, spotykały się $z$ problemami autochtonek. Przejawów aktywności Ligi w tym środowisku szukałam w zachowanej dokumentacji w Archiwum Państwowym w Katowicach, dotyczącej działalności LK i Wydziału Kobiecego Komitetu Wojewódzkiego PZPR w Katowicach. Temat referatu został przedstawiony głównie na podstawie tych źródeł. Celem artykułu jest zwrócenie uwagi na fakt, że w kręgu zainteresowań Ligi były także problemy, których doświadczały ślaskie autochtonki. Działaczki Ligi z różnym powodzeniem przełamywały bariery niechęci autochtonek do organizacji i polskiej administracji.

\section{Repolonizacja}

Akcja repolonizacji na Ślasku była prowadzona od $1945 \mathrm{r}$. w celu usunięcia wszelkich niemieckich śladów ${ }^{7}$. Oprócz wielu

\footnotetext{
4 Do uregulowania sytuacji i administracji na terenach Ziem Odzyskanych powołane zostało w 1945 r. Ministerstwo Ziem Odzyskanych. Działało do 1949 r. Dekret o zarządzie Ziem Odzyskanych z 13 XI 1945, (Dz.U. 1945, Nr 51, poz. 295) [online] [dostęp: 12.10.2020]. Dostępny w World Wide Web: isap.sejm.gov.pl.

5 W 1945 r. wysiedlono z Górnego Śląska ok. 150 tys. ludzi; Paweł Kacprzak, „Weryfikacja narodowościowa ludności rodzimej i rehabilitacja tzw. volksdeutschów w latach 19451949”, Czasopismo Prawno-Historyczne, t. 63, z. 2, 2011, 156.

6 W 1945 roku została powołana organizacja kobieca Społeczno-Obywatelska Liga Kobiet, która w 1949 r. zmieniła nazwę na Ligę Kobiet. W artykule używam zamiennie określeń Liga Kobiet i Liga oraz skrótu LK.

7 O sytuacji na Śląsku w pierwszych latach po wojnie: Janusz Pfaff, „Kursy repolonizacyjne na Śląsku Opolskim w latach 1945-1950”, Zeszyty Naukowe. Zbliżenia Cywilizacyjne, z. 13 (1), 2017, 54-89; Paweł Kacprzak, „Polityka władz polskich wobec ludności niemieckiej w okresie funkcjonowania Ministerstwa Ziem Odzyskanych", Czasopismo Prawno-Historyczne, t. 62, z. 2, 2010, 215-235; Paweł Kacprzak, „Weryfikacja narodowościowa ludności”, 149-164; Jan Drabina, Powojenne miesiące 1945 r. w Bytomiu, w: Bogdan Szlachta (red.), Myśl i polityka. Ksiega pamiątkowa dedykowana profesorowi Jackowi Marii Majchrowskiemu, t. 3, (Kraków: Wyd. Akademii Frycza Modrzewskiego, 2011), 23-34; Adam Miodowski, „Rozwój dolnośląskich i zachodniopomorskich struktur Społeczno-Obywatelskiej Ligi Kobiet
} 
działań (zmiany nazw ulic, urzędów, zmiany imion, spolszczanie nazwisk) dla rodowitych Ślązaków (dorosłych i młodzieży), którzy nie ukończyli polskiej szkoły, były organizowane kursy repolonizacji. Uczono na nich języka polskiego, słownictwa, z którego eliminowano germanizmy, polskiej historii i geografii, $z$ uwypukleniem łączności Śląska $z$ Polską oraz omawiano współczesne wydarzenia w Polsce i na świecie. Chociaż nazwa kursów, powszechnie zwanych „repolonizacyjnymi”, dla rodowitych Ślazaków (Polaków) mogła być obraźliwa, to były one konieczne. Wielu autochtonów znało język niemiecki, natomiast miało kłopoty $z$ czytaniem i pisaniem w języku polskim. Problem ten wypłynął w czasie organizowanych kursów dla analfabetów, w których organizację aktywnie włączyła się Liga Kobiet. Kursy repolonizacji zamiennie nazywano kursami języka polskiego lub nauki o Polsce ${ }^{8}$. Były darmowe, trwały trzy, cztery miesiace, ich uczestnicy otrzymywali świadectwa ukończenia ${ }^{9}$. Kursy nie dawały żadnych kwalifikacji zawodowych, ale były pomocne przy weryfikacji „polskości” ludzi, którzy podpisali volkslisty ${ }^{10}$. W skład komisji weryfikacji narodowościowej, oprócz przedstawicieli władz i partii, wchodził także przedstawiciel jakiejś organizacji, a wśród nich Ligi Kobiet. Organizacyjna wadą kursów było, że często prowadzili je ludzie przesiedleni na Śląsk (czyli obcy), którzy nie znali śląskiej gwary i niejednokrotnie nie posiadali odpowiednich kwalifikacji ${ }^{11}$.

Uczestniczkami kursów repolonizacyjnych w większości były kobiety. Na posiedzeniach plenarnych Zarządu Wojewódzkiego Ligi Kobiet w Katowicach w 1949 r., prowadzonych przez przewodniczaca Pelagię Dzidowska, omawiano sprawy obchodów Dnia Kobiet, współzawodnictwa, funkcjonowanie izb dworcowych oraz organizacji kursów. Kursy repolonizacyjne były organizowane w zakładach

w latach 1947-1949 w świetle publikacji "Naszej Pracy“", w: Małgorzata Dajnowicz, Adam Miodowski (red.), Polityka i politycy $w$ prasie XX i XXI wieku. Polityka $w$ prasie kobiecej, (Białystok: Wydawnictwo Uniwersytetu w Białymstoku, 2019), 167-183; Tomasz Browarek, „Polityka państwa polskiego wobec ludności rodzimej na ziemiach zachodnich i północnych w latach 1945-1949”, w: Robert Łoś, Jacek Reginia-Zacharski (red.), Sassiedztwo i pogranicze - między konfliktem a współpraca, t. 2, (Łódź: Wydawnictwo Uniwersytetu Łódzkiego, 2013), s. $147-164$.

8 21.02.1950 r. Ministerstwo Oświaty opublikowało Okólnik nr 3 w sprawie zasad organizacyjnych i egzaminów ukończenia kursów nauki o Polsce, (Dz.U. M.O. 1950, Nr 3, poz. 49, s. 38). Wcześniej w urzędowych dokumentach występowała nazwa „kursy repolonizacyjne”.

9 Janusz Pfaff, „Kursy repolonizacyjne”, 62.

10 Procesy weryfikacji narodowościowej i repolonizacji na Śląsku trwały pięć lat.

11 Janusz Pfaff, „Kursy repolonizacyjne”, 85. 
pracy. Na zebraniu 30 marca 1949 r. członkini Ligi Marciszowa informowała o zorganizowanym kursie repolonizacyjnym w Związku Poligraficznym w Bytomiu ${ }^{12}$. Można przypuszczać, że kursantkami były członkinie Ligi, chociaż w protokole nie ma takiej informacji. Inna członkini Ligi Gradecka $z$ PZS (Państwowe Zakłady Samochodowe?) relacjonowała, że na zakładowy kurs repolonizacyjny zgłosiło się 90 uczestników ${ }^{13}$.

W Gliwicach kursy repolonizacyjne organizował inspektor szkolny Konasiewicz, o czym informowała na zebraniu plenarnym Zarządu Wojewódzkiego LK i aktywistek związków zawodowych przewodniczaca Zarzadu Grodzkiego Ligi w Gliwicach J. Kowalska ${ }^{14}$. W tym wypadku także nic nie wiadomo o liczbie ligowych kursantek. Jednakże nawet te fragmentaryczne informacje świadcza o tym, że kursy repolonizacyjne były w kręgu zainteresowań Ligi Kobiet.

Proces repolonizacji mieszkańców regionu katowickiego oraz zaangażowania Ligi w pomoc autochtonkom przywołuje Małgorzata Fidelis w książce Kobiety, komunizm i industrializacja w powojennej Polsce ${ }^{15}$.

Chociaż działaczki Ligi Kobiet czy wydziałów kobiecych miały prowadzić pracę polityczną w imieniu komunistycznego państwa, często dochodziły do wniosku, że wzmacnianie polskiej tożsamości narodowej wśród Ślązaczek jest ważniejsze niż szerzenie nowej ideologii. Wydziały kobiece w zwiąkach zawodowych często koncentrowały się na kultywowaniu śląskich tradycji, widząc w nich przejaw polskości,

pisze Fidelis ${ }^{16}$.

Wbrew partyjnym zaleceniom eliminowania religii $z$ życia w niektórych gminach Liga Kobiet świadomie angażowała się w pielęgnowanie religijnych tradycji. W czasie weryfikacji narodowościo-

\footnotetext{
12 Archiwum Państwowe w Katowicach (dalej: APK), Liga Kobiet Zarząd Wojewódzki (dalej: LK ZW) Katowice, Zebranie ZW LK w Katowicach w dniu 30 marca 1949 r., sygn.12/290/2, k. 24.

13 APK LK ZW Katowice, Protokół z plenarnego zebrania członkiń Zarządu LK, aktywistek Związków Zawodowych Samopomocy Chłopskiej i Związków Zawodowych, sygn. 12/290/17, k. 5 .

14 Ibidem, k. 4.

15 Małgorzata Fidelis, Kobiety, komunizm i industrializacja w powojennej Polsce, tłum. Maria Jaszczurowska, (Warszawa: Wydawnictwo W.A.B., 2015). O sytuacji kobiet na Śląsku, autochtonach i repolonizacji, s. 147-188.

16 Małgorzata Fidelis, Kobiety, komunizm, 155.
} 
wej religia katolicka dla Ślązaków stała się wyznacznikiem ich polskości ${ }^{17}$.

W Wełnowcu ${ }^{18}$ zebrania koła Ligi rozpoczynały się śpiewem pieśni religijnych na cześć Boga, Dziewicy Maryi i Świętego Józefa. Organizowane przez Lige Kobiet uroczystości związane $z$ Dniem Matki (na Śląsku unikano obchodzenia komunistycznego Dnia Kobiet) rozpoczynały się nabożeństwem, a w akademiach uczestniczyli zapraszani kapłani.

\section{Autochtonki na uboczu}

Trudno ocenić, jak dokładnie układała się i przebiegała współpraca Ligi z autochtonkami. Skromne zapiski w protokołach zebrań świadczą o małej aktywności autochtonek w pracach Ligi. Kierowniczka Wydziału Opieki Społecznej ZW LK w Katowicach Barbara Radzikowska 7 maja 1949 r., na zebraniu powiatowych i grodzkich sekretarzy i przewodniczących sekcji kulturalno-oświatowych $z$ województwa ślasko-dąbrowskiego, apelowała, aby przy kierowaniu na kursy analfabetek zwracać szczególną uwage na autochtonki. I nie tylko skupiać się na kursach języka polskiego, ale otoczyć je stałą opieką i włączyć do prac w Lidze ${ }^{19}$. Włączanie do prac, według opinii członkiń Ligi, było trudne. Środowisko było zróżnicowane i podzielone, ludzie się nie znali (dużo napływowych mieszkańców). Autochtonki były uwikłane w procesy weryfikacyjne, spotykały się $z$ wieloma zakazami i $z$ nieufnością odnosiły się do polskich władz. „Dzielnica Sośnica [dzielnica Gliwic - dopisek M. B.-T.] jest bardzo ciężka w pracy, gdyż sa tam repatriantki i autochtonki", zanotowano w protokole 17 września 1949 r. ${ }^{20} \mathrm{Na}$ zebraniu Prezydium ZW LK w Katowicach 22 września 1949 r. stwierdzono, że zanika zapał do pracy kobiet wiejskich, nie uczestniczą we współzawodnictwie, bo nie były premiowane. „Trudności na wsi, to trudności polityczne. Ludność autochtoniczna ma pozostałości

\footnotetext{
17 Niemcy na Górnym Śląsku byli głównie wyznania ewangelickiego.

18 Wełnowiec był siedziba gminy, w 1951 r. został przyłączony do Katowic.

19 APK, LK ZW Katowice, Protokół posiedzenia powiatowych i grodzkich sekretarzy i przewodniczących sekcji kulturalno-oświatowych $z$ województwa śląsko-dąbrowskiego, odbytego 7 maja 1949 r., sygn. 12/290/ 2, k. 39.

20 APK, LK ZW Katowice, Komisja arbitrażowa z 17 września 1949 r., sygn. 12/290/2, k. 68 .
} 
po Niemcach", uważały działaczki i ten pogląd odzwierciedla zapis w protokole ${ }^{21}$. Na zebraniu mówiono o niemieckim sabotażu, o braku nowych członkiń wśród kobiet ze wsi, które nie były zainteresowane praca w Lidze. Zwrócono także uwagę na kolejki pod poczta, co zanotowano w protokole i co miało dowodzić, że autochtonki wysyłały listy i paczki do swoich rodzin w Niemczech, czyli według owczesnych ocen, utrzymywały kontakty z Niemcami. Była to pewnego rodzaju inwigilacja $\mathrm{i}$ interwencja $\mathrm{w}$ ich prywatność. Według władz ówczesne kontakty $z$ Niemcami, ale przecież $\mathrm{w}$ wielu wypadkach $z$ rodzinami, były naganne.

Napływowe działaczki Ligi traktowały autochtonki $z$ ostrożnością i $z$ dystansem prawdopodobnie $z$ powodu nieznajomości historycznych uwarunkowań i śląskich realiów. Przewodnicząca Zarządu Wojewódzkiego LK w Katowicach po nagłej śmierci Pelagii Dzidowskiej została poseł Maria Jaszczukowa, pochodząca $z$ Warszawy $^{22}$. W pierwszych powojennych latach niewielu rodowitych Ślązaków (przechodzili weryfikacje, odwołania, repolonizacje) uczestniczyło we władzach różnych szczebli w regionie oraz w życiu politycznym i społecznym. Takie odsunięcie autochtonów rodziło ich niechęć do władz polskich, do pracy w organizacji i izolację $\mathrm{w}$ środowisku. I było to widoczne także w szeregach Ligi.

Polityka narodowościowa władz zmieniła się w $1950 \mathrm{r}^{23}$ Zmianę poprzedziło utworzenie w 1949 r. dwóch państw niemieckich i inne nastawienie rzadu do Niemiec. A poza tym w $1950 \mathrm{r}$. przyjęto ustawę o planie sześcioletnim. Połączona $z$ nią była szeroka akcja zwiększania zatrudniania kobiet $z$ propagandowym wydźwiękiem zrównania praw kobiet i mężczyzn w pracy zawodowej ${ }^{24}$. Kobiety miały wykonywać prace budowlane, w kopalniach i hutach. Zmianę sytuacji odzwierciedlają dokumenty Komitetu Wojewódzkiego PZPR w Katowicach. „Stan pracowników nie jest odpowiedni, za mało pracuje Ślązaczek i autochtonek. Wojewódzki Zarząd nie

\footnotetext{
21 APK, LK ZW Katowice, Protokół z posiedzenia Prezydium ZW LK 22 września 1949 r., sygn. $12 / 290 / 2, \mathrm{k} .71$.

22 Maria Jaszczukowa, urodzona w Warszawie, była posłanka Sejmu Ustawodawczego (1947-1952) i Sejmu I kadencji (1952-1956), współtwórczyni Ligi Kobiet. Była żoną Bolesława Jaszczuka, także urodzonego w Warszawie, który w latach 1948-1950 był wojewoda ślaskim.

23 Paweł Kacprzak, „Polityka władz polskich”, 233.

24 Małgorzata Dajnowicz, „Liga Kobiet w okręgu łódzkim w latach 1945-1981. Główne obszary działalności organizacji”, Dzieje Najnowsze, nr 4, 2019, 81.
} 
analizował tego składu i nie starał się go poprawić", tak partia oceniła Zarząd Wojewódzki Ligi w sierpniu 1950 r. ${ }^{25} \mathrm{~W}$ 26-osobowym Zarządzie pracowały wówczas trzy autochtonki.

Posiedzenie egzekutywy KW PZPR w Katowicach 27 grudnia 1950 r. poświęcone było ocenie pracy Zarządu Wojewódzkiego Ligi, która skupiała wówczas 184 tys. członkin ${ }^{26}$. W przyjętej uchwale stwierdzono, że kobiety winny aktywnie włączyć się do planu sześcioletniego, który „stwarza wspaniałe perspektywy całkowitego wyzwolenia kobiety w Polsce". Organizacja miała propagować idee „sześciolatki”, nowe kwalifikacje i zawody kobiet oraz otaczać opieka matki pracujące i ich dzieci. Wówczas w Zarządzie Wojewódzkim Ligi w Katowicach, który tworzyło 46 kobiet, było siedem Ślazaczek i nie było żadnej autochtonki. Egzekutywa KW PZPR zwróciła uwagę na tę naganną sytuację. „Niedostateczna jest w Zarządzie Wojewódzkim Ligi ilość Ślązaczek i autochtonek. Podobna sytuacja istnieje we wszystkich zarząach terenowych", napisano w dokumencie ${ }^{27}$. Wada Ligi było także skupianie pracy na sprawach kobiecych, a nie na aktualnych zadaniach państwowych. Partia zalecała przeanalizować składy zarządów i włączyć do pracy w Lidze autochtonki. Ponadto należało podnosić świadomość ideologiczna kobiet oraz mobilizować je do realizacji pierwszego roku planu sześcioletniego.

Liga do akcji uświadamiających wykorzystywała różne okazje. Dla 28 żon górników z kopalni „Chorzów” zorganizowała wycieczkę, w czasie której aktywistki prowadziły rozmowy uświadamiajace. Przodownice Ligi w Gliwicach takie rozmowy prowadziły, zbierając należności za wodę. Aktywistki z Bytomia 150 rozmów przeprowadzily przy kopalni „Dymitrow” oraz wykorzystały dwa wesela, kiedy kobiety zebrały się na ulicy, by oglądać orszak weselny. Rozmawiały wówczas o... planie sześcioletnim ${ }^{28}$.

Liga oraz Wydział Kobiecy PZPR w Katowicach angażowały się w werbunek niezrzeszonych kobiet do pracy i do zdobywania przez nie nowych zawodów. Ale wyniki były niezadowalające.

\footnotetext{
25 APK, Komitet Wojewódzki Polskiej Zjednoczonej Partii Robotniczej w Katowicach $z$ lat 1948-1990 (dalej: KW PZPR w Katowicach), Ocena pracy Wojewódzkiego Zarządu Ligi Kobiet w Katowicach za okres 1 X 1949 do 1 VIII 1950, sygn. 12/1793/1, k. 33.

26 APK, KW PZPR w Katowicach, Uchwała Egzekutywy KW PZPR w Katowicach w sprawie pracy Wojewódzkiego Zarządu LK, sygn. 12/1793/1, k. 22.

27 Ibidem, k. 24.

28 APK, KW PZPR w Katowicach, Sprawozdanie z działalności Wydziału Kobiecego KW PZPR po linii węglowej, sygn. 12/1793/1, k. 63.
} 
W 1951 r. w Gliwicach było 32421 autochtonek, z których zatrudnione były 8223 kobiety $(25 \%)^{29}$. Wśród pracujacych $98,8 \%$ autochtonek było zatrudnionych jako pracownice niewykwalifikowane, robotnice $z$ najniższymi stawkami uposażenia. Nie zajmowały stanowisk kierowniczych, tylko pięć autochtonek pracowało w zakładowych biurach, gdzie zajmowały się sprawami pracowniczymi. Nieliczne autochtonki zatrudnione były jako maszynistki i kontystki (nazywano je „siłami podrzędnymi”). Wśród radnych w Gliwicach były tylko dwie autochtonki ${ }^{30}$.

Krytyczna była uchwała Wojewódzkiego Wydziału Kobiecego PZPR w Katowicach.

Uchwały Biura Politycznego KC PZPR w sprawie pracy wśród autochtonów i zadania stojace na tym odcinku nie zostały przez Wydział Kobiecy rozpracowane i zrealizowane. ... Wydział Kobiecy rozpracuje szczegółowo metody pracy wśród autochtonek i przyciagnie je do udziału w pracy organizacji partyjnych i organizacji masowych. Śmielej będzie wysuwać autochtonki na stanowiska kierownicze w organizacjach masowych,

nakazano ${ }^{31}$

Mimo partyjnych dyrektyw i uchwał w środowisku autochtonki nadal były „inaczej” traktowane. Przewodnicząca Rady Kobiet $z$ kopalni „Śląsk” towarzyszka Prokop w czasie narady roboczej 22 maja 1952 r. przedstawiła sytuację ze swojego zakładu. W kopalni Rada Kobieca zaproponowała, aby na wolne miejsce w centrali telefonicznej skierować młodą dziewczynę. Spotkała się z odmowa $z$ powodu... podpisanej przez kandydatkę volkslisty ${ }^{32}$. Prokop apelowała: „trzeba skończyć z wysuwaniem sprawy volkslisty”. Poznając taki apel, można przypuszczać, że prawdopodobnie nie było to wyjatkowe zdarzenie. Podobna sytuacja miała miejsce $\mathrm{w}$ fabryce w Szopienicach. Pracownica Syrek z tej fabryki chciała wstapić do partii. Przy jej nazwisku umieszczono notatkę: „ma III volkslistę na

${ }_{29}$ APK, LK ZW Katowice, Protokół z posiedzenia Prezydium WZ LK w dniu 2 października 1951 r., sygn. 12/290/3, k. 114.

30 APK, LK ZW Katowice, Sprawozdanie dotyczące ludności autochtonicznej (kobiet) na terenie miasta Gliwice $z$ dn. 30 września 1951, sygn. 12/290/3, k. 116-117.

31 APK, KW PZPR w Katowicach, Projekt uchwały Wojewódzkiego Wydziału Kobiecego, sygn. 12/1793/1, k. 75-76.

32 APK, KW PZPR w Katowicach, Protokół z narady roboczej aktywu kobiecego Zwiazku Zawodowego Górników odbytej w dniu 22 maja 1952 roku w Katowicach sygn. 12/1793/3, k. 10. 
odwołanie, jej ojciec służył w wojsku niemieckim, a brat jest porucznikiem wojska niemieckiego ${ }^{33}$.

Autochtonki były też nieobecne w Lidze, która zabiegała o masowość i organizowała dla kobiet wiele kursów z różnych dziedzin. Do Ligi należało ok. 10\% autochtonek. W 1950 r. Liga w Gliwicach przeszkoliła 372 autochtonki (w kursie maszynopisania uczestniczyło 85, a w kursie kroju i szycia 75). Sekretarz Zarządu Grodzkiego LK w Gliwicach Urbańska przyznała, że Zarząd nie organizował systematycznych akcji werbunkowych w stosunku do tych kobiet. Do Zarządu należały tylko dwie autochtonki. „Troska o autochtonów była niewystarczająca, raczej sporadyczna, nie miała charakteru planowego", napisała w sprawozdaniu sekretarz Urbańska ${ }^{34}$.

Śląaczki mogły czuć się obco. Składały wnioski o uzyskanie zgodny na wyjazd $z$ Polski. Na polecenie Zarząu Wojewódzkiego Ligi Kobiet w Katowicach w sierpniu i wrześniu 1951 r. Zarząd Grodzki w Gliwicach badał warunki autochtonek, które zgłosiły chęć wyjazdu do Niemieckiej Republiki Demokratycznej. Działaczki LK odwiedziły 150 rodzin. W wyniku tej akcji 22 osoby podjęły pracę, 37 zadeklarowało uczestnictwo w kursie, 52 osoby były w wieku starszym i nie zdecydowały się na pracę i kurs, a 39 stwierdziło, że nie podejmie żadnej pracy i nie zgłosi się na żaden kurs.

„Kobiety te na ogól niechętnie odnoszą się do możliwości szkolenia zawodowego, zaplanowanego na bieżący rok szkolny przez Miejską Radę Narodową i Zarząd Grodzki Ligi Kobiet”, oceniła sekretarz Urbańska ${ }^{35}$. Działaczki Ligi kilkakrotnie spotkały się $z$,nieprzychylnym ustosunkowaniem się ludności rodzimej, wymyślając je w ordynarny sposób", zanotowano w sprawozdaniu. Większość autochtonek, do których dotarła Liga, pogodziła się z pozostaniem w Polsce i prosiła o poprawę warunków bytowych.

W Gliwicach w 1951 r. zaplanowano objać akcją opieki 565 autochtonek. We wrześniu 1951 r. Liga prowadziła nabór na pięć kursów. Na kurs trykotarski zgłosiło się 6, na hafciarski-3, pantoflarski -5 , cerowania artystycznego -3 , rachunkowości (dla rozliczeniowców i kalkulatorów) - 13 osób, a na kurs galanterii skórzanej nikt ${ }^{36}$.

\footnotetext{
33 APK, KW PZPR w Katowicach, Sprawozdanie z Kolegium KM PZPR w Szopienicach z 6 sierpnia 1952 r., sygn. 12/1793, k. 154.

34 APK, LK ZW Katowice, Sprawozdanie dotyczące ludności autochtonicznej, k. 116.

35 Ibidem.

36 Ibidem, k. 117.
} 
Działaczki Ligi starały się przezwyciężać trudności. Badały warunki bytowe autochtonek (z zapomogi mogły skorzystać tylko zweryfikowane), organizowały pomoc wdowom i matkom $z$ licznym potomstwem. Sieroty Liga kierowała do domu małego dziecka, organizowała szkolenia, 375 skierowała do pracy. W Gliwicach wówczas brakowało 120 miejsc w żłobkach i przedszkolach. Kobiety, które chciałyby pracować, nie miały komu powierzyć opieki nad dziećmi. Autochtonkami i ich rodzinami w regionie interesowały się także władze miast, głównie wydziały opieki społecznej i za pośrednictwem nauczycieli wydziały oświaty (opieka nad dziećmi, sierotami, półsierotami).

Na zebraniu prezydium Zarządu Wojewódzkiego Ligi w Katowicach 5 sierpnia 1953 r. zwrócono uwagę, aby notować wypowiedzi kobiet $z$ terenów autochtonicznych, by poznać panujące wśród nich nastroje. Tego samego roku Zarząd Główny LK wyznaczył limit tworzonych świetlic w rejonie katowickim. Miało powstać sześć. Zarząd Wojewódzki w Katowicach zdecydował wówczas, że trzy świetlice zostana utworzone na terenach autochtonicznych w Zabrzu, Toszku i Bytomiu. Liga zgodnie z partyjnymi wytycznymi podejmowała próby dotarcia do autochtonek i przekonania ich do organizacji, a pośrednio także do nowej władzy.

\section{Podsumowanie}

W pierwszych powojennych latach autochtonki znalazły się w niezwykle trudnej sytuacji politycznej. Ich nieufność wobec władz rodziły decyzje weryfikacyjne i repolonizacyjne (udowodnianie polskości, naciski na zmianę imion i nazwisk). Narastał także niepokój przed ostatecznym werdyktem komisji weryfikacyjnej.

Liga Kobiet była utożsamiana $z$ nową władzą. Kiedy na Górnym Śląsku budowała swoje struktury i powiększała szeregi o członkinie $z$ Kresów Wschodnich i przyjezdne $z$ centralnej Polski, autochtonki były jeszcze pochłonięte sprawami weryfikacyjnymi. W niektórych oddziałach, jak w Wełnowcu, Liga pomagała kobietom $\mathrm{w}$ tym trudnym okresie. $\mathrm{W}$ innych regionach raczej nie interesowała się autochtonkami. Przybyłe na Sląsk $z$ innych regionów kraju działaczki Ligi nie znały śląskich realiów, historii, języka i nie rozumiały Ślazaczek. Autochtonki były nieobecne we władzach i w życiu publiczno-społecznym. Partia i Liga poważnie zainteresowały się nimi w czasie wdrażania planu sześcioletniego. Po pięcioletnim „autowaniu” autochtonek trudno było przełamać barierę nieufności. 


\section{Bibliografia}

\section{Archiwalia}

Archiwum Państwowe w Katowicach, zespoły:

Liga Kobiet Zarząd Wojewódzki w Katowicach,

Komitet Wojewódzki PZPR w Katowicach z lat 1948-1990.

\section{Opracowania}

Browarek, Tomasz. „Polityka państwa polskiego wobec ludności rodzimej na ziemiach zachodnich i północnych w latach 19451949", w: Robert Łoś, Jacek Reginia-Zacharski (red.), Sasiedztwo i pogranicze - między konfliktem a współpraca, t. 2, (Łódź: Wydawnictwo Uniwersytetu Łódzkiego, 2013), 147-164.

Dajnowicz, Małgorzata. „Liga Kobiet w okręgu łódzkim w latach 1945-1981. Główne obszary działalności organizacji”, Dzieje Najnowsze, nr 4, 2019, 75-90.

Drabina, Jan. „Powojenne miesiące 1945 r. w Bytomiu”, w: Bogdan Szlachta (red.), Myśl i polityka. Ksiega pamiatkowa dedykowana profesorowi Jackowi Marii Majchrowskiemu, t. 3, (Kraków: Wyd. Akademii Frycza Modrzewskiego, 2011), 23-34).

Fidelis, Małgorzata. Kobiety, komunizm i industrializacja w powojennej Polsce, Maria Jaszczurowska (tłum.), (Warszawa: Wydawnictwo W.A.B., 2015).

Kacprzak, Paweł. „Polityka władz polskich wobec ludności niemieckiej w okresie funkcjonowania Ministerstwa Ziem Odzyskanych”, Czasopismo Prawno-Historyczne, t. 62, z. 2, 2010, 215-235.

Kacprzak, Paweł. „Weryfikacja narodowościowa ludności rodzimej i rehabilitacja tzw. volksdeutschów w latach 1945-1949", Czasopismo Prawno-Historyczne, t. 63, z. 2, 2011, 149-164.

Miodowski, Adam. „Rozwój dolnośląskich i zachodniopomorskich struktur Społeczno-Obywatelskiej Ligi Kobiet w latach 19471949 w świetle publikacji "Naszej Pracy", w: Małgorzata Dajnowicz, Adam Miodowski (red.), Polityka $i$ politycy $w$ prasie $X X$ i XXI wieku. Polityka w prasie kobiecej, (Białystok: Wydawnictwo Uniwersytetu w Białymstoku, 2019), 167-183.

Pfaff, Janusz. „Kursy repolonizacyjne na Śląsku Opolskim w latach 1945-1950", Zeszyty Naukowe. Zbliżenia Cywilizacyjne, z. 13 (1), 2017, 54-89.

Roszkowski, Wojciech. Historia Polski 1914-1991, (Warszawa: Wydawnictwo Naukowe PWN, 1992). 


\section{Źródla internetowe}

Dekret o zarządzie Ziem Odzyskanych z 13 XI 1945, (Dz.U. 1945, Nr 51, poz. 295) [online] [dostęp: 12.10.2020]. Dostępny w World Wide Web: isap.sejm.gov.pl.

Postanowienie SN - III SK 20/06 [online] [dostęp: 1.06.2020]. Dostępny w World Wide Web: https://prawo.money.pl/orzecznictwo/sad-najwyzszy/postanowienie. 